\title{
Trends in Poverty and Income Inequality in Urban Malaysia: Emerging Issues and Challenges
}

\author{
Ferdoushi Ahmed", Md. Shahin Mia, Aree Wiboonpongse, Sutonya Thongrak, Sirirat \\ Kiapathomchai
}

\begin{abstract}
Malaysia has experienced rapid urbanization and infra structure development during the past few decades. Objective of this study to assess the nature of poverty and income inequality in the urban areas in Malaysia. The study also aims to focus on the emerging issues and challenges of rapid urbanization and urban poverty in the country. Secondary data were obtained from the Economic Planning Unit (EPU), Malaysia and the Department of Statistics, Malaysia. The analyses show that though the rate of urban poverty followed a declining trend during the last few decades, incidence of poverty and hard-core poverty still exists in the urban areas of the country. It was also found that earnings of the urban dwellers increased gradually during the past few decades. But income inequality in urban localities remained wider (Gini coefficient is, on average, 0.453). Moreover, income disparity among the major ethnic groups (Malays, Chinese and Indians) in the country is greater and sizeable. The continuation of urbanization, urban poverty and income inequality bring forward new issues and challenges. Therefore, to handle these issues and challenges, it is urgently required to identify the effectiveness of specific programs as well as design and best practice of urban poverty reduction programs and policies.
\end{abstract}

Index Terms: Keywords: Urban Poverty, Income Inequality, Emerging Issues, Challenges, Malaysia.

\section{INTRODUCTION}

In the recent decades, urban poverty has been one of the major interesting research subjects due to the impacts of the urbanization in developing countries around the world. The growing interest in urban poverty in developing countries has been brought about by various factors such as rural bias in the past development strategies, rapid rates of urbanization, rural urban migration and structural transformation of the economies of these countries (Asian Development Bank 2014). It is recognized that rural and

Revised Manuscript Received on September 22, 2019.

Ferdoushi Ahmed, Faculty of Economics, Prince of Songkla University (PSU), Hat Yai, Songkhla, Thailand, ferdoushi.a@psu.ac.th

Md. Shahin Mia, School of Economics, Finance and Banking (SEFB), College of Business (COB), Universiti Utara Malaysia (UUM), Kedah, Malaysia

Aree Wiboonpongse, Faculty of Agriculture, Chiang Mai University, Chiang Mai, Thailand and Centre of Excellence in Econometrics, Faculty of Economics, Chiang Mai University, Chiang Mai, Thailand

Sutonya Thongrak, Faculty of Economics, Prince of Songkla University (PSU), Hat Yai, Songkhla, Thailand

Sirirat Kiapathomchai, Faculty of Economics, Prince of Songkla University (PSU), Hat Yai, Songkhla, Thailand. urban poverty are interrelated and overall success of poverty eradication programs requires a balanced approach. Urban population has increased very rapidly and is expected to continue for the coming decades especially in the developing countries. In 1950, for example, urban population in developing nations was less than 300 million and it increased to 1.1 billion in 1985 (UNCHS 1996). The study projected that more than 4 billion people will be living in the major urban conurbations of developing nations by the year 2025. Between 1990 and 2000, the annual population growth and built areas were only $0.6 \%$ and $2.9 \%$ respectively for the developed nations (World Bank 2005). However, in the developing countries, the annual population growth and built-areas were $1.8 \%$ and $3.6 \%$ respectively. In this high speed rate of growth, managing urbanization has become a major challenge among planners and decision makers in both developed and developing nations (Devas and Rakodi 1993; Choguill 1994). The acceleration of urbanization has been accompanied by increase of urban poverty together with crowding, uneven distribution of development benefits and change in the ecology of urban environment (Mok et al. 2007). Urban poverty can lead to multiple deprivations which in turn can bring about cumulative impacts on the urban poor. In addition, urban poverty is a dynamic condition of vulnerability due to urban management (Aziz et al. 2011).

Since the introduction of the New Economic Policy 1971-1990 (NEP), Malaysia has achieved outstanding progress in poverty eradication. During this period the poverty incidence has dropped from $52.4 \%$ in 1970 s to $15 \%$ 1990s (Economic Planning Unit, Malaysia 2004). The rate of poverty in the country has further decreased to $5.5 \%$ in 2000, 3.8\% in 2009 and 0.7 percent in 2012 (Hasan and Hashim 2001; Muhamed and Haron 2011; Chukwukere and Baharuddin 2012; Department of Statistics, Malaysia 2013). Recently it was reported that only $1.7 \%$ of the Malaysian population is living below the overall poverty line (Economic Planning Unit, Malaysia 2013). It is a good sign that Malaysia has achieved in advance one facet of the UN Millennium Development Goals to eradicate extreme poverty and hunger to enhance the development paradigm of 'growth with equity' and the country is able to embark on the next phase of development

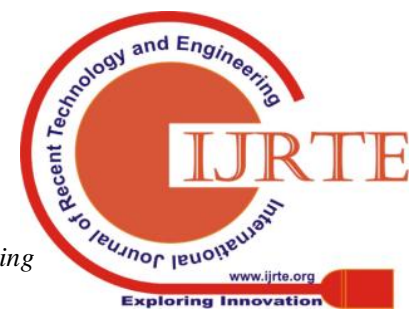


to become a fully developed country in its own mould by the year 2020 (UNDP 2005). However, poverty continues to be a major development concern in the country (Othman and Kari 2008; Nair 2010). Particularly, Now-a-days, urban poverty in Malaysia is an increasingly visible phenomenon. The growth in urban population in the country swelled from $30 \%$ in 1960 to $40 \%$ in 1980 and to $60 \%$ in 2000 (World Bank 2015). The growth in urban population has been due to natural increase in urban population, rural urban migration, reclassification of rural areas and the increase in built up areas. It was predicted that the level of population in urban areas of the country will continue to intensify and urbanization will reach about $75 \%$ by the year 2020 and three quarter of total population of the country will be staying in urban areas by the year 2030 (National Physical Plan of Malaysia 2010).

High speed of urban expansion in the country has caused various problems for local government especially in fulfilling the provision of services and infrastructures, and providing houses for urban dwellers (Elhadary and Samat 2012). Excessive urban growth has also resulted in uneven distribution of development benefits between urban centers as well as between rural-urban areas leading to some degree of regional imbalances (Siwar and Kasim 1997). Furthermore, the gaps of income and other socioeconomic well beings of people in the country has widened not only regionally but also ethnically (Rostam et al. 2010). Therefore, to tackle the problems, identifying the location of poor in urban areas, income inequality among the people in urban areas, effective design and best practise of urban poverty reduction policies and programs are required (Siong 2008). However, rural poverty has always occupied the centre stage in Malaysia's development policy, strategies and programs. On the other hand, urban poverty has received a cursory attention and focus. Moreover, there is lack of research on examining the impacts of growing urbanization on urban poverty and income inequality among the urban areas in the country.

The objective of the present study is to assess the nature of poverty and income inequality in the urban areas in Malaysia. The study also aims to focus on the emerging issues and challenges of rapid urbanization and urban poverty in the country.

\section{MATERIALS AND METHODS}

The present study is based on secondary data on urban poverty, overall poverty, urban population, household income and Gini coefficient of urban population, and urbanization in Malaysia during the last few decades. The data were collected from the Economic Planning Unit (EPU), Malaysia and the Department of Statistics (DOS), Malaysia. To assess poverty status, the households were divided into two groups (viz. poor and hard-core poor) based on poverty line income (PLI) defined by the Malaysian government. PLI for a household is measured in combination of two components, i.e. food PLI and non-food PLI (Muhamed and Haron 2011). Incidence of poverty and hard-core poverty were determined as follows:

\section{A. Incidence of Poverty:}

A household is considered poor if its income is less than PLI (i.e. food PLI plus non-food PLI). Therefore, the incidence of poverty can be measured as follows:

Incidence of poverty $=\frac{\text { No. of poor households }}{\text { No. of population }} \times 100$

\section{B. Incidence of Hard-Core Poverty:}

A household is considered hard-core poor if its income is less than food PLI. Therefore, the incidence of hard-core poverty can be measured as follows:

No. of hard-core poor households

Incidence of hard-core poverty $=\ldots$ 100

No. of population

Descriptive statistics (viz., summation, mean, frequency and percentage) were applied to analyze distribution of population, movement in urbanization and household income, incidence of urban poverty and overall poverty in the country during the last few decades.

Gini coefficients were assessed to see the trends of income inequality of the households at urban as well as national level during the past few decades. The value of the Gini coefficient ranges from 0 to 1 , where the value 0 corresponds to perfect equality (e.g. everyone has the same income) and 1 corresponds to perfect inequality (e.g. one person has all the income, and everyone else has zero income). And large Gini coefficients imply greater degrees of income inequality.

\section{RESULTS AND DISCUSSIONS}

\section{A. Rising in urban population and urbanization in Malaysia}

Table I depicts the trend of total and urban population in Malaysia from 1970 to 2010. The data showed that total population and urban population were 10.44 millions and 2.82 millions respectively in 1970s. After that the country experienced cumulative increase of both total and urban population during the last few decades. It can be seen that that the growth in urban population swelled from $27 \%$ in 1970 to $71 \%$ in 2010 . The rising trend in urban population was due to mainly population migration from rural to urban areas as well as the natural population growth in urban areas. The increased proportion of population in urban areas is expected to be continued and to reach about $75 \%$ by the year 2020 (National Physical Plan of Malaysia 2010). The exponential increase in urban population contributed to the acceleration of urbanization in the country. 
Table I: Total and urban population in Malaysia (1970-2010)

\begin{tabular}{|c|c|c|c|}
\hline \multirow[b]{2}{*}{ Year } & \multirow[b]{2}{*}{$\begin{array}{l}\text { Total Population } \\
\text { (million) }\end{array}$} & \multicolumn{2}{|c|}{ Urban Population } \\
\hline & & $\begin{array}{l}\text { Population } \\
\text { (million) }\end{array}$ & $\begin{array}{l}\% \text { of total } \\
\text { population }\end{array}$ \\
\hline 1970 & 10.44 & 2.82 & $27 \%$ \\
\hline 1980 & 13.14 & 4.47 & $34 \%$ \\
\hline 1991 & 17.57 & 8.90 & $51 \%$ \\
\hline 2000 & 23.30 & 14.45 & $62 \%$ \\
\hline 2010 & 28.60 & 20.31 & $71 \%$ \\
\hline
\end{tabular}

Source: Department of Statistics, Malaysia 2011

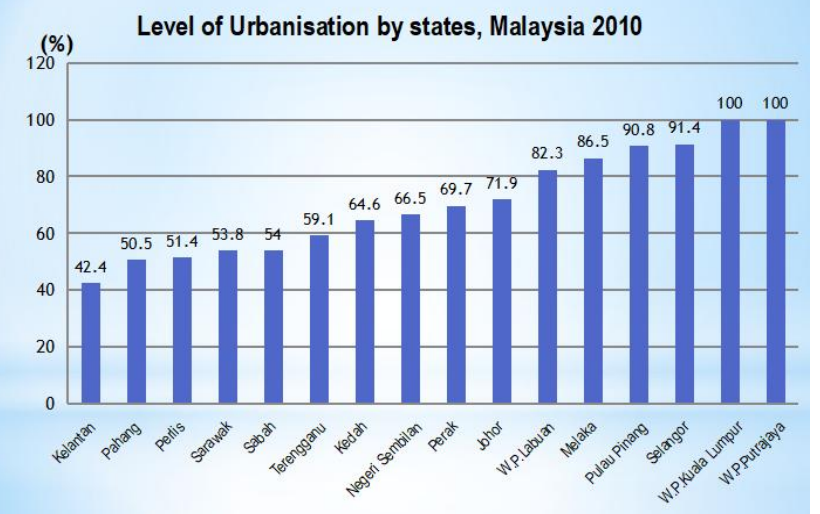

Fig. 1: Level of urbanization by states in Malaysia, 2010 (Source: Department of Statistics, Malaysia 2011)

Fig. 1 depicts the level of urbanization by states in the country for the year 2010. It can be seen that the greatest urbanized state in Malaysia was Selangor in 2010 (level of urbanization was 91.4\%). The state of Pulau Pinang and Melaka ranked the $2^{\text {nd }}$ and $3^{\text {rd }}$ position in terms of urbanization in the country (level of urbanization was $90.8 \%$ and $86.5 \%$ respectively). On the other hand, the level of urbanization in the state of Perlis, Pahang and Kelantan were significantly lower $(51.4 \% \quad 50.5 \%$ and $42.4 \%$ respectively). It is important to note that the Federal Territory of Kuala Lumpur and Putra Jaya were fully urbanized (level of urbanization was $100 \%$ ) by the year 2010. Urban population is concentrated in 6 major conurbations of Kuala Lumpur, Georgetown, Johor Bahru, Kuantan, Kota Kinabalu and Kuching (Department of Statistics, Malaysia 2011).

\section{B. Urban Poverty and Hard-core Poverty in Malaysia}

In recent years, urban poverty in Malaysia has been considered as an increasingly visible phenomenon due to the impacts of the urbanization. The rate of poverty at urban and national level in Malaysia during 1970- 2012 is presented in Table 2. The highest incidence of poverty at both urban and national level was observed in the year of 1970 (25.5\% and $49.3 \%$ respectively). The rate of urban poverty as well as overall poverty of the country decreased tremendously in the year 1976 (15.4\% and $37.7 \%$ respectively). However, there was an increase in urban poverty in the year 1979 (17.5\%). After that there was an overall decreasing trend in urban poverty during the last three decades. A similar pattern was observed in overall poverty incidence in the country. On the other hand, incidence of hard-core poverty at both urban and national level was found to be highest in the year 1984 (2.4\% and $6.9 \%$ respectively). However, the rate of hard-core poverty at urban as well as national level decreased gradually during the subsequent three decades. The findings suggest that the incidence of poverty and hard-core poverty at both urban and national level followed a declining trend though there were ups and downs in poverty incidence in each stratum.

Table II: Urban and overall poverty incidence in Malaysia (1970-2012)

\begin{tabular}{lllll}
\hline \multirow{2}{*}{ Year } & \multicolumn{2}{l}{$\begin{array}{l}\text { Incidence of Poverty } \\
(\boldsymbol{\%})\end{array}$} & \multicolumn{2}{l}{$\begin{array}{l}\text { Incidence of Hard-core } \\
\text { Poverty }(\boldsymbol{\%})\end{array}$} \\
\cline { 2 - 5 } & Urban & Overall & Urban & Overall \\
\hline 1970 & 25.5 & 49.3 & - & - \\
1976 & 15.4 & 37.7 & - & - \\
1979 & 17.5 & 37.4 & - & - \\
1984 & 8.5 & 20.7 & 2.4 & 6.9 \\
1987 & 8.5 & 19.4 & 1.9 & 5.1 \\
1989 & 7.1 & 16.5 & 1.3 & 3.9 \\
1992 & 4.7 & 12.4 & 1.0 & 2.9 \\
1995 & 3.6 & 8.7 & 0.9 & 2.0 \\
1997 & 2.1 & 6.1 & 0.4 & 1.4 \\
1999 & 3.3 & 8.5 & 0.5 & 1.9 \\
2002 & 2.3 & 6.0 & 0.3 & 1.0 \\
2004 & 2.7 & 5.7 & 0.4 & 1.2 \\
2007 & 2.0 & 3.6 & 0.3 & 0.7 \\
2009 & 1.7 & 3.8 & 0.2 & 0.7 \\
2012 & 1.0 & 1.7 & 0.1 & 0.2 \\
\hline
\end{tabular}

Source: Economic Planning Unit, Malaysia 2012

\section{Urban Household Income and Inequality in Income}

Urban and overall household income in Malaysia during 1970-2012 is depicted in Figure 2. It can be seen that the average household income per month at both urban and national level was significantly low in 1970s (below MYR1,000). However, the urban household income was comparatively higher than overall household income in the country. And earnings of the urban dwellers increased gradually during the past few decades. Similarly, household income at national level was found to be increased on a regular basis after 1970s. The findings indicate that urban and overall household income in the country followed an upward trend during the last few decades and crossed the level of MYR5,000 in 2012. 


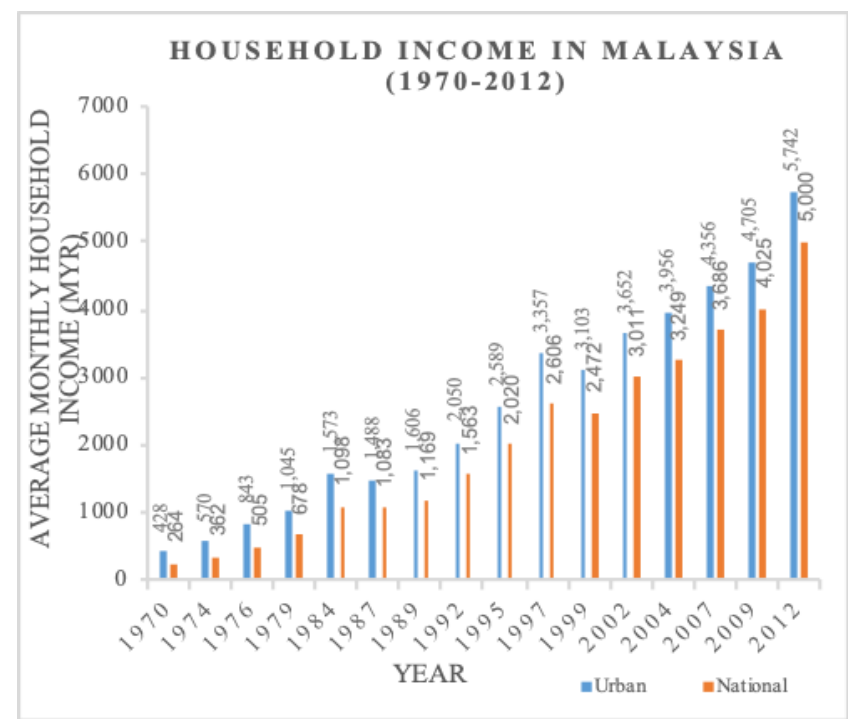

Fig. 2: Urban and overall household income in Malaysia (1970-2012)

(Source: Economic Planning Unit, Malaysia 2012)

Table III presents the Gini-coefficient data on average income inequality at urban and national level in Malaysia between 1970 and 2012. The analyses show that inequalities in household income at both urban and national level were significantly high in 1970s (Gini co-efficient is higher than 0.50). However, income inequality in urban localities are comparatively lower than overall income inequality in the country. It can be seen that there was an overall decreasing trend in urban income inequality during the last few decades. A similar pattern was observed in overall income inequality in the country. The findings suggest that the rate of Gini ratio both at urban and national level followed a declining trend though there were ups and downs in income inequality in each stratum. The data also indicate that the income gaps in urban localities as well as national level still remain wider.

Table III: Income inequality (Gini Co-efficient) at urban and national level in Malaysia (1970-2012)

\begin{tabular}{lll}
\hline \multirow{2}{*}{ Year } & \multicolumn{2}{l}{ Income inequality $($ Gini Co-efficient) } \\
\cline { 2 - 3 } & Urban & Overall \\
\hline 1970 & - & 0.513 \\
1974 & 0.541 & 0.530 \\
1976 & 0.531 & 0.557 \\
1979 & 0.491 & 0.505 \\
1984 & 0.468 & 0.483 \\
1987 & 0.440 & 0.456 \\
1989 & 0.444 & 0.442 \\
1992 & 0.439 & 0.459 \\
1995 & 0.431 & 0.456 \\
1997 & 0.427 & 0.459 \\
1999 & 0.432 & 0.443 \\
2002 & 0.439 & 0.461 \\
2004 & 0.444 & 0.462 \\
2007 & 0.427 & 0.441 \\
2009 & 0.423 & 0.441 \\
2012 & 0.417 & 0.431 \\
\hline
\end{tabular}

(Source: Economic Planning Unit, Malaysia 2012)
Income inequality is a major concern in particular for multiracial countries like Malaysia because ethnically more homogenous populations tend to have more equal income distributions (Alesina and Glaeser 2004; Saari et al. 2015). This is supported by the growing body of economic literature that finds that ethnic heterogeneity induces social conflicts and violence, which in turn, affects economic growth (Easterly and Levine 1997; Mauro 1995; Montalvo and Reynal-Querol 2005). Figure 3 shows the income disparity across the ethnoic groups in Malaysia between 1970-2002. It can be sen that in 1970, the average income of the Malays (i.e. Bhumiputera- the largest group that is the poorest on average) was the lowest among the three major ethnic groups in the country. It follows that income increased for all ethnic groups in the period 1970-1990, income of the Malays expanded more than the income of the Chinese and Indians. However, compared with 1970, inequality in income among the ethnic groups increased in 1990. In the period 19902002, income growth was the highest for Chinese, followed by Indians and Malays. Consequently, income inequality within each ethnic group further widened and showed sizeable during 1990-2002.

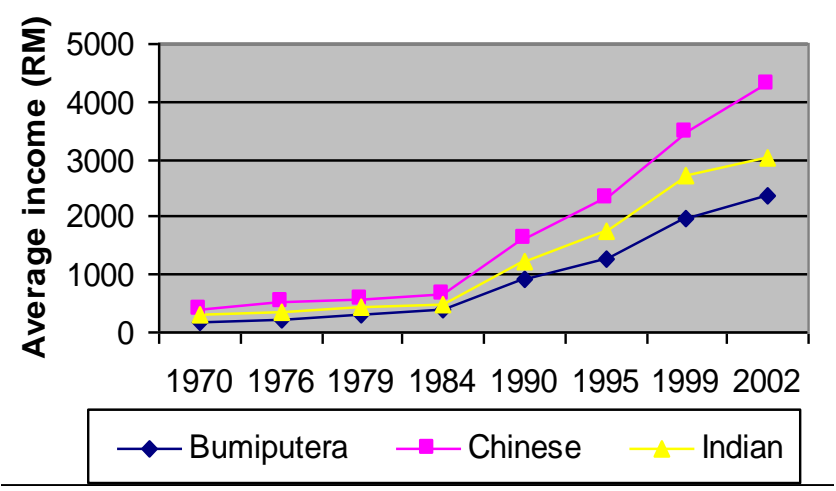

Fig. 3: Income disparity across ethnic groups in Malaysia (1970-2002)

(Source: Department of Statistics, Malaysia 2006)

\section{Emerging issues and challengea of urban poverty and income inequality}

Rapid urbanisation, urban growth and rural-urban migration act as the main contributors to urban poverty and income inequality in Malaysia (Ragayah 2008). Urban poverty is a multi-dimensional phenomenon which is related with a number of issues and challenges (Siwar and Kasim 1997; Elhadary and Samat 2012). The emerging issues and challenges related with urban poverty and income inequality in Malaysia are discussed below:

\section{E. Issues:}

\section{1) National unity:}

National unity is defined as a situation in which loyalty and dedication (of the diverse elements of the Malaysian population) to the nation should over-ride all other loyalties. National unity was determined as the only goal to underscore its paramount importance in national development and

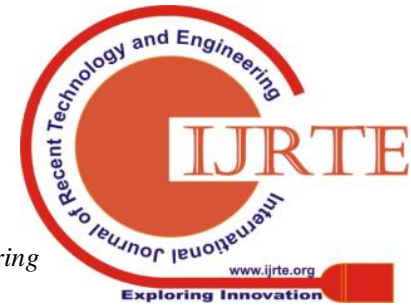


nation building and to prevent the dilution of its importance if others goals were included. Poverty and inequalty is one of the important constraints for natioanl unity. The ethnic riots on 13 May 1969 and Kg Medan incidence on 4 March 2001 are the reflections of racial clashes due to poverty and inequalities amongst ethnic groups (Shari 2000; Faaland et al. 2003; Saari et al. 2015). The negative consequences of ethnic diversity imply that adequate policies are required to ensure that the benefits of economic growth are equally shared among all ethnic groups.

\section{2) Urban gentrification:}

Urban gentrification is the process of urban renewal and arrival of middle class or wealthier people in an existing urban district, a related increase in rents and property values, and changes in the district's character and culture. In other words, urban gentrification is the displacement of poor communities by rich outsiders. People who grew up in urban environment are forced to move to other cheaper urban environment because their earning capacity cannot match the increased cost of obtaining dwellings in their original urban locales. It brings forward serious consequences on racial harmony and racial balance. In Malaysian metropolitan cities and larger urban centers like Penang, Ipoh, Johor Bahru, etc similar phenomenon is happening, with the urban poor being displaced and marginalized to the urban suburbs (Siong 2008). Majority of urban poor are moving into low-cost and smaller houses/cramped apartments built by DBKL and PKNS. Moreover, property and wealth ownerships in urban centres are highly unequal. Participation of the urban poor in business in urban centres is minimal. They mainly operate restaurants and food courts and petty trades in the outer urban business districts/ periphery.

\section{3) Cost of Living:}

Cost of living in urban areas generally tends to be higher as the basic needs of life for example food, housing, education, medical facilities and transportation are more expensive than that in rural areas. Urban poor are the direct sufferer of higher cost of living. The poor people in urban localities are forced to take on additional jobs or work overtime for extra income to meet up the higher cost of living. In some cases, they are forced to access into the trap of debt. It can be said that urban poor are more prone to be poorer because of higher cost of living

\section{4) Unemployment:}

Urban poverty occurs when the city is not able to provide job opportunities for its dwellers and there is stiff competition to get a well-paid job. Unemployment is one of the main characteristics of urban poverty. Unemployment in Malaysia is highest among young job seekers (Economic Planning Unit, Malaysia 2015). Unemployment problems will be aggravated for the local population with the influx of foreign labour, estimated to be about 3 million, a greater portion of them working in construction and services sectors in urban areas.

\section{5) Crime and Social Problems:}

Poverty is closely connected with social problems and criminal misconduct. The extent of absolute and relative poverty may considered as a significant determinant of crime, along and possibly in connection with the preceding social factors in developing countries. Urban development/renewal force the poor people to be placed in low-cost flats/cramped apartments (shrinking in sizes) which creates various social problems such as illegal drug, unintended pregnancy and high rates of single-parent family. Inadequate housing is also a major contributor to social breakdown and crime such as gangsterism, juvenile delinquency, and domestic violence. The crime will rise because the poor are forced to commit crimes for the survival of life in the city (Economic Planning Unit, Malaysia 2015). The increase of crime will inevitably lead to reduced quality of life and give a bad image to foreign investors.

\section{F. Challenges:}

1. Poverty and inequalities can certainly hinder national unity. It is a big challenge for Malaysia to bring its multiple racial groups in national unity.

2. Challenges remain in ensuring an adequate supply of quality housing, solving urban congestion and protecting the environment at the local and national policy level (Siong 2008).

3. It is also a challenge for the country to reduce urban poverty and improve infrastructure development while maintaining a balance with achieving high investments in urban areas.

4. Another challenge for the Malaysian government is to reduce income inequality among the ethnic groups (UNHSP 2013).

5. Challenges remain with coverage at secondary level of school, and boys from poorer households in particular are increasingly at risk of dropping out of school (World Bank 2013)

6. Reducing dependency on foreign labor is another challenge for the country to decrease the rate of poverty and income inequalty in the urban areas of the country.

\section{CONCLUSION}

The present study assesses the nature of urban poverty and income inequality in Malaysia during the past few decades. The study also attempts to highlight the emerging issues and challenges of rapid urbanization and urban poverty in the country. The high growth of urbanization in Malaysia during the last few decades has been characterized by the growth of large cities and metropolitan cities in the country. The exponential increase in urban population also contributed to the acceleration of urbanization in the country. The greatest urbanized state in Malaysia was Selangor, followed by Pulau Pinang and Melaka (level of urbanization was $91.4 \%, 90.8 \%$ and $86.5 \%$ respectively) in 2010. Urban poverty and

income inequalty are
considered the
consequences of rapid
Published By:
Blue Eyes Intelligence Engineering Exploring Innovation
\& Sciences Publication


urbanization. Though the rate of urban poverty followed a declining trend during the last few decades, incidence of poverty and hard-core poverty still exists in the urban areas of the country. Income inequality in urban localities also remained wider (Gini coefficient is, on average, 0.453) during the past few decades. Moreover, income disparity among the major ethnic groups in the country is greater and sizeable. The government implemented a good number of policies, programs and strategies during the last few decades to alleviate urban poverty. However, the continuation of urbanization, urban poverty and income inequality bring forward new issues (such as national unity, urban gentrification, higher cost of living, unemployment, crime and social problems) and challenges. Therefore, to handle these issues and challenges, it is urgently required to identify the effectiveness of specific programs as well as design and best practice of urban poverty reduction programs and policies.

\section{ACKNOWLEDGMENTS:}

The authors would like to thank the Economic Planning Unit (EPU), Malaysia and Department of Statistics (DOS), Malaysia for providing the data.

\section{REFERENCES}

[1] Alesina, A., and Glaeser, E., 2004. Fighting poverty in the U.S. and Europe: A world of difference. Oxford: Oxford University Press.

[2] Asian Development Bank, 2014. Urban Poverty in Asia: Asian Development Bank,

[3] Mandaluyong City 1550 Metro Manila, Philippines. Available at: https://www.adb.org/sites/default/files/publication/59778/urban-poverty -asia.pdf

[4] Aziz, W.N.A.W.A., Ahmad, F., Hanif, N.R. and Kok, W.H., 2011. Pembasmian Kemiskinan Bandar ke arah Bandar Inklusif dan Sejahtera: Cabaran Kuala Lumpur. Journal of Surveying, Construction and Property, 2 (1): 107-124.

[5] Choguill, C. L., 1994. Implementing Urban Development Projectsa search for criteria for success; Third World Planning Review, 16 (1) 25-40.

[6] Chukwukere, O.A. and Baharuddin, A.H., 2012. Risk and poverty in agriculture: Expanding roles for agricultural cooperatives in Malaysia. Geografia, 8 (4): 1-11.

[7] Department of Statistics, Malaysia, 2006. Malaysia economic statistic Time series. Department of Statistics, Malaysia, Putrajaya, Malaysia.

[8] Department of Statistics, Malaysia, 2013. Household Income and Basic Amenities Survey Report. Available at http://www.statistics.gov.my/portal/download_household/files/househol d/2009/HISBA Publication 2009.pdf. Pp. 1-139.

[9] Department of Statistics, Malaysia, 2011. Population distribution and basic demographic characteristics- population and housing census of Malaysia 2010. Department of Statistics, Malaysia, Putrajaya, Malaysia. Pp. 4.

[10] Devas, N. and Rakodi, C. 1993: Planning and Managing Urban Development. In: Devas, N. / Rakodi, C. (Eds.): Managing fast growing cities. New Approaches to Urban Planning and Management in the Developing World. New York: Longman Scientific and Technical.

[11] Easterly, B., and Levine, R., 1997. Africa's growth tragedy: Policies and ethnic divisions. Quarterly Journal of Economics, 112(4): 1203-1250.

[12] Economic Planning Unit, Malaysia, 2004. Malaysia: 30 Years of Poverty Reduction, Growth and Racial Harmony. Economic Planning Unit (EPU), Prime Minister's Department, Putrajaya, Malaysia.

[13] Economic Planning Unit, Malaysia, 2012. Socio-economic statisticshousehold income and poverty. Economic Planning Unit (EPU), Prime Minister's Department, Putrajaya, Malaysia.

[14] Economic Planning Unit, Malaysia, 2013. The Malaysian Economy in Figures. Economic Planning Unit (EPU), Prime Minister's Department, Putrajaya, Malaysia.Pp. 35.

[15] Economic Planning Unit, Malaysia, 2015. Achieving a System of Competitive Cities in Malaysia. Mian Report. Economic Planning Unit (EPU), Prime Minister's Department, Putrajaya, Malaysia.Pp. 35.
[16] Elhadary, Y.A.E and Samat, N., 2012. Political Economy and Urban Poverty in the Developing Countries: Lessons Learned from Sudan and Malaysia. Journal of Geography and Geology, 4 (1). doi:10.5539/jgg.v4n1p212.

[17] Faaland, J., Parkinson, J., and Saniman, R., 2003. Growth and ethnic inequality. Kuala Lumpur: Utusan Publications and Distributions.

[18] Hasan, A.R. and Hashim, S., 2001. Poverty Statistics in Malaysia.Department of Statistics, Malaysia, Putrajaya, Malaysia.

[19] Matul, M., 2005. Demand for Microinsurance in Georgia. Qualitative Study Results.Microfinance Centre for Central and Eastern Europe and the New Independent State.

[20] Mok, T.Y., Gan, C., Sanyal, A., Division, C., Box, P.O. and Zealand, N., 2007. The Determinants of Urban Household Poverty in Malaysia. Journal of Social Sciences, 3(4): 190-196. doi:ISSN 1549-3652.

[21] Montalvo, J.G., and Reynal-Querol, M., 2005. Ethnic diversity and economic development. Journal of Development Economics, 76(2): 293-393.

[22] Muhamed, K and Haron, S., 2011: Poverty mapping: an effective approach in determining the poor area- case study of Johor. Department of Statistics, Malaysia, Putrajaya, Malaysia.

[23] Nair, S., 2010. Moving forward: Its poverty agenda challenges, dilemmas and options for Malaysia. Paper prepared for CPRC Conference, 8-10 September 2010.

[24] National Physical Plan of Malaysia, 2010. Available at: http://www.kpkt.gov.my/kpkt_2013/fileupload/dasar/NPP.pdf

[25] Othman, A. and Kari, F., 2008. Enhancing co-operatives movement to achieve Malaysia's development goals.Paper presented at the ICA Research Conference, October2008, riva del Gardea,Trento Italy.

[26] Ragayah, M.Z., 2008. Income distribution and sustainable economic development in EAST Asia. A comparative analysis. Ed. Ragayah Haji Mat Zin and Medhi Krongkaew. East Asian Development Network. Universiti Kebangsaan Malaysia. Malaysia. pg.196.

[27] Rostam, K., Jali, M.F.M and Toriman, M.E., 2010. Impacts of Globalisation on Economic Change and Metropolitan Growth in Malaysia: Some Regional Impications. The Social Sciences,5(4): 293-301.

[28] Saari, M.Y., Dietzenbacherd, E. and Los, B., 2015. Sources of Income Growth and Inequality Across Ethnic Groups in Malaysia, 1970-2000. World Development, 76: 311-328.

[29] Shari, I., 2000. Economic growth and income inequality in Malaysia, 1971-95. Journal of the Asia Pacific Economy, 5(1-2): 112-124.

[30] Siong, H.C., 2008. Urban Governance and Rapid Urbanization Issues in Malaysia. Jurnal Alam Bina, Jilid 13(4): 1-24.

[31] Siwar, C. and Kasim, M.Y., 1997. Urban development and urban poverty in Malaysia. International Journal of Social Economics, 24(12): 1524-1535. doi:10.1108/03068299710193958

[32] UNCHS (United Nations Commission on Human Settlements), 1996. An Urbanizing World: Global Report on Human Settlements 1996, Oxford University Press, Oxford.

[33] UNDP (United Nations Development Programs), 2005. Malaysiaachieving the millennium development goals, successes and challenges. United Nations Country Team, Malaysia. Available at: http://www.undp.org.my/uploads/MDG full report.pdf. Pp. 1-256.

[34] UNHSP(United Nations Human Settlement Programme), 2013. State of the World's Cities 2012/2013: Prosperity of Cities.

[35] World Bank, 2005. Overview: Understanding, measuring and overcoming poverty. Available at: http://www.colorado.edu/philosophy/healthwood/pdf/worldbank.pdf.

[36] World Bank. 2013. "Malaysia Economic Monitor: High-Performing Education." December, 2013. The World Bank. Bangkok.

[37] World Bank, 2015. Malaysia Economic Monitor: Transforming Urban Transport. Southeast Asia Country Management Unit, The World Bank. Available http://documents.worldbank.org/curated/en/509991467998814353/pdf/ 97393-WP-P152893-Box391466B-PUBLIC-MEM12-Draft-v3-3b.pdf

\section{AUTHOR PROFILE}

Ferdoushi Ahmed, my affiliation is Faculty of Economics, Prince of Songkla University (PSU), Hat Yai, Songkhla, Thailand, my area of research is social sciences.

Md. Shahin Mia, School of Economics, Finance and Banking (SEFB), College of Business (COB), Universiti Utara Malaysia (UUM), Kedah, Malaysia my research area is social sciences. 
Aree Wiboonpongse, Faculty of Agriculture, Chiang Mai University, Chiang Mai, Thailand and Centre of Excellence in Econometrics, Faculty of Economics, Chiang Mai University, Chiang Mai, Thailand. My research area is social sciences.

Sutonya Thongrak, my affiliation is Faculty of Economics, Prince of Songkla University (PSU), Hat Yai, Songkhla, Thailand. My research area is Social sciences.

Sirirat Kiapathomchai, I am associated with Faculty of Economics, Prince of Songkla University (PSU), Hat Yai, Songkhla, Thailand. My research area is social sciences. 